\title{
Fighting Greed with Money: How Wage Levels Impact Corruption in the Private Purchasing Sector
}

\author{
GABRIELA DE LA TORRE CAMPOS \\ FH Joanneum, Austria \\ gabriela.delatorrec@gmail.com \\ KATHARINA RADLER \\ FH Joanneum, Austria \\ katharina.radler@hotmail.com \\ BRAMANTIO UTOMO SAPTOADI \\ F H Joanneum, Austria \\ bramantio.saptoadi@edu.fh-joanneum.at
}

The purpose of this research is to see whether different wage levels in the private purchasing sector relate to the level of corruptibility. An experiment was conducted that put participants in the role of employees of a purchasing department of a multinational enterprise. The employees were allotted to different wage levels and had to choose between options with different levels of corruption. The research is of a deductive nature and complemented by a descriptive quantitative approach containing the Chi-Square analysis. The results show that there is no association between the wage level and the level of corruptibility of employees in the private purchasing sector. This outcome contributes to the underresearched field of corruption in the private sector and gives further insight into the influence of wages on corruptibility, as well as the usability of the principal-agent theory in the field of corruption.

Key words: corruption, purchasing sector, private sector, wage levels, principal-agent theory https://doi.org/10.26493/1854-4231.12.355-374

\section{Introduction}

Corruption is a complex social, political and economic phenomenon. Due to the many aspects involved in the concept of corruption, a comprehensive definition is hard to create (Ortiz-Ospina and Roser 2016). Nevertheless, the following definition can grasp the core of the concept: 'Corruption is the abuse of entrusted power for private gain' (see https://www.transparency.org/what-is-corruption). 
The importance of the topic of corruption is undeniable in all countries worldwide. It can impact societies on a variety of levels - from politics to the economy, from social impact to environmental factors (see https://www.tranpsarency.org/what-is-corruption). Tackling the problem of corruption would not only lead to a more just distribution of money, it is further assumed that it would be a working measure against organised crime, better enforce the rule of law and enhance trust in public institutions (European Parliamentary Research Services 2016). On an economic level, less corruption would lead to more just competition and more stable market structures (see https://www.transparency.org/what-is-corruption). However, the effects of corruption are not only severe in emerging and developing markets. A recent study by European Parliamentary Research Services (2016) estimate the annual cost of corruption in GDP terms in the $\mathrm{EU}$ between 179 and 990 Billion Euro.

As a result, finding the causes and the ways to stop corruption have been the aim of the observed research field, especially in the last two decades, which leads to a vast amount of literature concerning the topic of corruption. However, while there seems to be evidence on what favours corruption on a macro-level, at a micro-level, there is not as much understanding as to what the contributing factors for corruption are (Dusek, Ortmann, and Lízal 2005). Furthermore, as corruption is generally a secretive and often illegal topic, it is quite difficult to measure, whether with hard or soft data (OrtizOspina and Roser 2016). This leads to the need for ongoing research and new ways of trying to understand the phenomenon of corruption.

When scrutinising current literature about corruption it becomes apparent that most research is focused on the public sector. Public sector will be defined in this paper as the 'portion of the economy composed of all levels of government and government-controlled enterprises' (see https://www.britannica.com/topic/public-sector), in comparison to the private sector, which includes 'all for-profit businesses that are not owned or operated by the government' (see https://www.investopedia.com/terms/p/private-sector.asp). Reasons for the focus on the public sector are stated by various authors. For example, Gray and Kaufmann (1998) see it as far more sees privateto-private corruption even less studied and states further reasons why the private sector has not been regarded as much as the public sector. Firstly, he assumes that the public sector will have better measures to stop corruption as it is in the own interest of the managers to stop their employees from being corrupt. Secondly, he believes 
that, as there are less incentives and a more effective competition, public-to-public corruption might not be as big of an issue. Thirdly, and this might be the most interesting reason in our regard, research does not concern itself so much with corruption on a private level, as there is less attention and information regarding the topic.

Argandoña's (2003, 254) last argument already leads to the reason why corruption in the private sector needs to be more in the focus of contemporary corruption research. He further adds that ' $[. .$. private-to-private corruption has been relatively neglected, this kind of corruption is important, no less widespread, no less harmful' and '[t]he subject has become increasingly important in recent years.' Impactful institutions, such as the International Monetary Fund $(2016,21)$ see it as imperative that 'enforcement should also target the private sector.' Ernest and Young's international business corruption report $(2015,21)$ found out that $51 \%$ of companies state that 'bribery/corrupt practices happen widely in business in this country,' but $42 \%$ of the interviewed companies have no anti-corruption measures set in place. Also public impression of the problem shows that citizens are concerned about the danger of corruption in the private sector. Transparency International (2016) found out that the corruption among business executives is $26 \%$ according to the perception of participating citizens in Europe and Central Asia. This sum up to a definite need for a new focus in research on the reasons and mechanics of corruption in the private sector.

\section{Research Gap and Literature Review}

In order to specify the existing research gaps, primarily literature in the field of corruption and the principal-agent theory was regarded. For the field of corruption, mainly research about the corruption in the private sector influencing determinants on corruption as well as working methodologies in the sensitive field of corruption were scrutinised. As stated before, the lack of research concerning private corruption was apparent. Therefore, in a first step understanding what drives employees in the private sector to act corrupt had to be understood. Rashid and Rashid (2012) found out that employees of the public and the private sector have in fact different types of motivations. Their research proved that, as shown in other literature, 'Public sector employees were more motivated by work contents and experience more balance between work and family life, whereas, private sector employees are more motivated by financial rewards, career development opportunities, and supportive environment [...]' (p. 24). 
In the case of corruption research, many possible determinants of what can prevent people from acting corrupt have been scrutinised in former literature. Examples for this are monitoring, punishment, or transparency measures. An interesting and highly controversial determinant in this regard is the topic of wages, which is widely discussed in corruption research. From the early work of Becker and Stigler (1974), whose paper shows that rising wages along with monitoring can be used as an anticorruption strategy, conventional knowledge, as well as literature, both theoretical and empirical, suggest that one of the main causes of bribery in the public sector are actually the low wages (Goel and Nelson 1996; Klitgaard 1988; Van Rijckeghem and Weder 2001). This made it an interesting topic to be regarded in the light of private-to-private corruption.

On the one hand, Barr, Lindelow, and Serneels (2004) found evidence that suggest that public servants who receive a higher wage are less corrupt, but that the effect is small. Van Rijckeghem and Weder's (2001) research finds that large increases in civil-service pay will be an effective measure against corruption. In addition, Azfar and Nelson (2007) found that corruption will be reduced by increasing government wages and the difficulty to hide a corrupt act or gain. Moreover, Boly and Armantier (2011) found that the effect of higher wages could be quite ambiguous. Meaning that higher wages lead to lower bribe acceptance, but at the same time, they foster reciprocation. On a very logical level, Frank and Schulze (2003) argue that either reciprocity of receiving a higher wage and therefore wanting to work harder for the employer or the enhanced opportunity costs, if the well-paid job is lost, might lead to lower corruption through high wages.

On the other hand, Frank and Schulze's research (2003) found that agents are not less corrupt when adding a fixed payment in addition or independently of a bribe. However, when adding monitoring to the equation, fixed payment became a significant influence on corruption. In addition, Abbink (2000) could not find evidence that high relative salaries lead to less corruption, even with fairness considerations. Besley and McLaren (1993) agree in their research by stating that the necessary wage level would be too high to be cost-effective, when either the possibility of detection is too low or the bribe too high. Overall, we can see that there is no set agreement as to if high wages can lower corruption, at least in the public sector.

Furthermore, corruption is likely to happen in the procurement or purchasing area. Since, according to the $\operatorname{OECD}(2016,6)$, there is evidence that 'public procurement is vulnerable to corruption. [...] 
more than half of foreign bribery cases occurred to obtain a public procurement contract.' Besides, according to Passas (2007, 4), 'Procurement is an area that has long been recognized as being particularly vulnerable to fraud and corruption.' Hence, the decision was to also focus on the purchasing/procurement area, but this time within the private sector.

The data of research in the field of corruption is usually collected through direct observations, like audit reports or from perception survey, like public opinion surveys (Ortiz-Ospina and Rosa 2016). However, experiments on corruption and corruptibility, which seem a very fitting approach to finding causes and solutions (Dusek, Ortmann, and Lízal 2005), are few and far between. This resulted in the choice of conducting an experiment in the current research.

From the reviewed experiments, it was decided to take Frank and Schulze's experiment (2000; 2003) as a basis, but with several modifications, which are explained in detail below. The main reason to use the model of Frank and Schulze (2000; 2003) was that the model of their experiment has a clear mechanism that can be applied well in the chosen context of this research. Nonetheless, Frank and Schulze address a variety of possible factors that might influence corruption. This experiment is going to single out the factor of fixed wages. This comes on the one hand from the above-explained disputed debate about the topic. On the other hand, it is also an area in which the former experiment leaves space for further development. Frank and Schulze $(2003,158)$ state, 'For future research, it would be interesting to study whether it makes any difference if the agents' salary is paid directly by the principal instead of the experimenters.' This matter will be implemented in this research, also if just in artificial form. Furthermore, Frank and Schulze (2000; 2003) just use fixed payments; using fixed wages might lead to different effects as it implies results for a longer timeframe.

Regarding the underlying theory, Frank and Schulze (2000, 49) state, 'Corruption can be regarded as a special manifestation of the familiar principal-agent problem. The agent has an incentive to favor a third party at the expense of the principal and in exchange for some compensation (the bribe).' Besides the fact that the basis for the current research used this theory, the principal-agent theory (РAT) was also chosen as the underlying theory because it is well applicable in the field of corruption (Graf Lambsdorff 2002; Persson, Rothstein, and Teorell 2010). Furthermore, the PAT was proved to be an interesting approach, as there are quite contrary opinions about the use of fixed wages to fight corruptibility (Jost 2011; Sappington 
1991; Fehr, Gächter, and Kirchsteiger 1997; Pratt and Zeckenhauser 1981).

In short, the aim of this paper is to help fill the research gap found between the focus of high wages as a tool for lowering corruption, and the research of corruption in the private purchasing sector through an experiment. This experiment was constructed in a way that the participant, or agent, played the role of an employee in a purchasing department of a company. In the company, an important machine breaks down and it is the responsibility of the respondent to choose one of the offers made by several repairing companies. His/her employer does not see, if the employee chooses a favourable offer or not. The employee has the chance to choose between ten different repair companies based on two values. Firstly, how much the service to repair the machine will cost his/her employer, and secondly, how much the employee receives from the repair company in order to choose it. This choice represented the dependent variable. It can therefore be seen how corrupt the participant would act in the specific situation, if he/she accepts the bribery, 'the giving or offering of the bribe' (see https://en.oxforddictionaries.com/definition/bribery) from the other party. Moreover, there were three sets of questionnaires with three different wage levels, representing the independent variable.

\section{RESEARCH QUESTIONS AND HYPOTHESIS}

From the resulting research gap, the subsequent research questions, which will be answered in this paper, emerged:

1. Do low wages for employees working in the private purchasing sector increase corruptibility?

2. Do high wages for employees working in the private purchasing sector lower corruptibility?

The purpose of this paper is therefore to examine whether a difference can be observed in the behaviour of agents that receive different levels of wages. The research will show if different wage levels will drive the agent to act more or less corrupt.

This will result in the following hypothesis:

$\mathrm{H} 1$ Low wages are related to the different levels of corruption in the private purchasing sector.

This means that respondents in the low wage category will act differently than respondents in the two higher wage classes concerning their tendency towards corruption. 
н2 High wages are related with different levels of corruption in the private purchasing sector.

This means that respondents in the high wage category will act different from respondents in the two lower wage classes concerning their tendency towards corruption.

\section{Theoretical Background}

The underlying theory for the current paper is the Principal-Agent Theory. This theory was chosen out of the following reasons.

Firstly, Frank and Schulze (2000; 2003) use the theory as a background of their experiment. Therefore, it seems reasonable to choose it also for the present experiment, as the ground-laying mechanism is the same and the results will be comparable.

Secondly, in general, authors contest the PAT a 'great analytical clarity' (Levacic 2009, 33), by showing a clear mechanism in a simple manner (Kivistö 2008; Klitgaard 1988). Furthermore, it allows showing a holistic view of trade-offs and thereby grants to show a realistic process of actions. (Johnston 2008; Klitgaard 1988). On the other side, the main criticism against the used theory - that it is not well applicable in all contexts and that the principal might not always be benevolent (Johnston 2008; Arthurs and Busenitz 2003; Broadbent, Dietrich, and Laughlin 1996; Graf Lambsdorff 2002; Klitgaard; Graf Lambsdorff 2001; Aidt 2003) - do not matter in the current experiment. This clearly shows that the advantages of the theory can be used, while the disadvantages of the theory do not apply in the current research, which gives it a strong informative value and confirms its use.

Thirdly, the PAт is linked to all crucial parts of the experiment. Incentives play an important role in the mechanism of the theory (Bamberg, Coenenberg, and Krapp 2008), which supports the focus on wages. For the field of corruption it is even called the 'predominant theory' (Persson, Rothstein, and Teorell 2010, 4), which further underlines its usability for the current experiment.

As the PAT is a well-developed and commonly used theory, it will only be explained in its most basic functionality and with reference to the current research. The elementary PAт sees two parties as decisive: The principal, who is the 'affected party' that needs another party to conduct a certain action. He/she knows about their aims and tries to convince the agent, which usually has an information advantage, to act in his/her favour. The agent is thereby the 'acting party' that fulfils the demanded action, but usually with a wide 


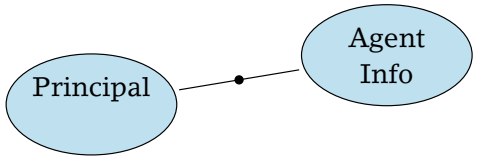

FIGURE 1 Information Asymmetry

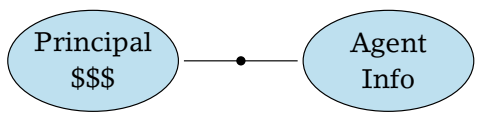

FIGURE 2 Effect of Incentives

range of possibilities in what way he/she can conduct the demand by the principal. The relation is regulated by a contract, which sets the framework of the cooperation (Pratt and Zeckenhauser 1991; Jost 2001, 13).

The PAT starts from the assumption that 'the principal cannot perfectly and costlessly monitor the agent's action and information' (Pratt and Zeckenhauser 1991, 2). Therefore, the PAT aims at being an instrument that helps finding the best structure for minimizing the costs of the second-best solution, which are referred to as the 'agency loss' and therefore raise the overall welfare benefit to the highest level possible (Pratt and Zeckenhauser 1991, 2).

In the current experiment, the underlying problem is the Moral Hazard, or also named 'hidden action' (Kiener 1990, 23). In this case, both parties had the same amount of information before and during the conclusion of the contract, but afterwards the principal has an information disadvantage (Schwaiger and Meyer 2011).

Literature discusses ways out of the Moral Hazard trap. Bamberg, Coenenberg, and Krapp (2008) state two ways of tackling the problem. Firstly, the principal could monitor all actions of the agent. However, this seems too costly and would therefore go against the principle of aiming at the maximisation of the overall benefit. Therefore, the second solution, giving incentives to the agent in order to make him/her comply with the principal's wishes, seems to be the better solution. Nevertheless, also the incentives have to include certain functions in order to be effective: the mechanism must be visible by both parties and must have an easily understandable underlying structure, so that the agent can see how his/her actions affect the outcome (Bamberg, Coenenberg, and Krapp 2008).

As can be seen, the PAT sees a solution of the principal-agent problem in offering the right incentives (Bamberg, Coenenberg, and Krapp 2008). Furthermore, the PAT assumes that all agents aim for their highest possible income. This does not mean that the actors only strive for monetary incomes, but as monetary incentives can be easier expressed in economic terms, they are mostly used in the PAT (Jost 2001). In the PAT, both parties want to maximise their personal benefit. While for the principal this means to get the most profit out 
of his/her undertaking, for the agent this means to earn the most with the least effort. Therefore, the crucial question is how to design wage schemes in order to align the aims of the principal and the agent (Jost 2001). This question is widely discussed in literature.

As a conclusion of the reviewed literature about the PAT it can be said that fixed wages in view of the theory are mainly criticised due to the fact that they do not show a clear relation between the effort that is put into work and the received incentive (Jost 2001; Pratt and Zeckenhasuer 1985). Furthermore, the principal would need to determine the fixed wage before knowing the characteristics of the agent (Sappington 1991). On the other side, research from Fehr, Gächter, and Kirchsteiger (1997) affirms the effectiveness of wages and Jost (2001) sees advantages of fixed wages in e.g. securing the agent against market risk or facilitating the payment scheme in continuous workflows, such as assembly lines.

\section{Methodology}

The following part will explain the experimental design and give insight into the data collection.

\section{EXPERIMENTAL DESIGN}

As mentioned before, the current experiment was based on the previous experiment by Frank and Schulze (2000; 2003). However, some changes were made to make it fitting to the context of the private purchasing sector. In order to understand how the content was developed, the following paragraphs will show how the current experiment was constructed based on Frank and Schulze's experiment (2000; 2003).

In Frank and Schulze's experiments (2000; 2003), students were asked to fill in a questionnaire before going into movies of the student's film club. The role of the participants was to act as an agent that has to decide which plumber company to choose in order to save a 200 German Mark bill of the film club that had fallen down a drainpipe. Also in Frank and Schulze's experiment, ten plumber companies with rising corruption levels were given as options. Half of the students would be promised a fixed payment of 40 German Mark after their contribution. Furthermore, through adding the chance of being detected for some students with and without the promise of a fixed payment, their studies were able to regard not only the influence of fixed payments, but also monitoring. Further hypothesis treated the influence of study programmes the students were enrolled in, as well as the gender of the respondents. High importance 
was added to make the situation as much based on common knowledge as possible.

To make the experiment fit to the chosen context of the private purchasing sector, the following decisions were made.

First, in order to align it with the context of the private purchasing sector, the student's film club was changed into a multinational company. The participants of this experiment had to play the role of the 'agent,' in that case an employee working in the purchasing department of said company. In this way, it was also easy for them to imagine or picture any real company, just as the students' organization on the previous experiment from Frank and Schulze (2000).

Second, the fixed payment of Frank and Schulze's experiment (2000; 2003) were changed into a fixed wage. The wages were decided on an average income of someone working in the purchasing sector with 5 years of experience (Pramböck 2014). The lower and higher level wages were always approximately a third more or less from this average wage, resulting in a low level net wage of $1.700 €$, a medium level net wage of $2.400 €$ and a high level net wage of 3.100 $€$. This complies with the reality in the purchasing sector in Austria, since the experiment is done in this country and the average salaries in the sector might be common knowledge.

Third, since the context for the present experiment is more formal, it was decided to change the bill lost in the drainpipe to the fixing of a very important and expensive machine used by the company. Moreover, the plumber company was simply changed to a 'repair company.'

Fourth, it was decided to leave the same amount of choices, meaning ten, in order to have a good range. However, the amounts from the offers by the repairing companies ('The price the film club has to pay') and the sum the agents could get ('The amount you receive') was changed (Frank and Schulze 2000, 105). The reason behind it was that, in the present experiment, the amount had to match the repairing of a very expensive machine, as opposed to the retrieving of a bill from a drainpipe. Equal to the former experiment, one of the options was left with 'o' as the amount the agent could receive, in order to portrait it as the 'no corruption' option. The offers were also presented in a table, for an easier visualization as seen in table 1.

Finally, the amounts that have been used for the current research project lower the overall benefit in every step in order to be in line with the assumption of PAT and the initial model of Frank and Schulze $(2000 ; 2003)$. This means that corruption will not make a maximization of the overall benefit possible, as the Principal-Agent- 
TABLE 1 Corruption Levels

\begin{tabular}{|c|c|c|c|c|c|}
\hline (1) & (2) & (3) & (1) & (2) & (3) \\
\hline $\mathrm{R} 1$ & $500 €$ & $\mathrm{o} €$ & R6 & $2,650 €$ & $300 €$ \\
\hline R2 & $850 €$ & $75 €$ & R7 & $3,200 €$ & $380 €$ \\
\hline R3 & $1,200 €$ & $150 €$ & R8 & $3,600 €$ & $450 €$ \\
\hline R4 & $1,650 €$ & $190 €$ & R9 & $4,000 €$ & $510 €$ \\
\hline R5 & $2,100 €$ & $240 €$ & R10 & $6,000 €$ & $600 €$ \\
\hline
\end{tabular}

Notes Column headings are as follows: (1) repair company, (2) price that your employer has to pay, (3) amount that you receive from the repair company.

Theory aims at (Dietz 1998). This means that for every more corrupt step, there will be a higher overall cost:

Price the company has to pay $\left(R_{X}\right) \quad$ Price the company has to pay $\left(R_{X}+1\right)$

- Amount received by the employee $<-$ Amount received by the employee

$\begin{array}{cl}\left(R_{X}\right) & \left(R_{X}+1\right) \\ \text { Overall Benefit } & \text { Overall Benefit }\end{array}$

In addition, three questions asking for classification information were included, in order to see the demographical background of the respondents (Malhotra 2012).

\section{DATA COLLECTION}

The questionnaire was distributed virtually as well as per hand. For the online distribution, the platform 'Question Pro' was used. The link was spread via social media, as well as a with a data list of 1033 employees in the private purchasing sector. Via this distribution, exactly 100 people took part in the online questionnaire. Physically, the questionnaire was distributed on different events and locations in the city of Graz, Austria. Besides a fair, also different events of the FH Joanneum Graz were visited, which led to the high response rate of younger people. Overall, 384 valid responses were collected.

As the instructions explained the situation, anyone could imagine the context and act as the purchasing manager. Therefore, everyone older than 15 years old could take part in the experiment. This age limit was set based on the minimum age for working in Austria, as it was believed that from this age on the role of the employee could better be imagined (see https://www.help.gv.at/Portal.Node/hlpd/ public/content/171/Seite.171520.html).

\section{Results}

The chosen method to analyse the collected answers was the Chi Square method. The reasons for choosing this method of testing 
TABLE 2 Frequency Distribution

\begin{tabular}{|c|c|c|c|c|c|}
\hline \multicolumn{2}{|l|}{ Gender } & \multicolumn{2}{|l|}{ Age } & \multicolumn{2}{|c|}{ Work experience } \\
\hline Female & 166 & $15^{-18}$ years & 9 & No work exp & 48 \\
\hline Male & 199 & $19-24$ years & 160 & $<2$ years & 71 \\
\hline Other & 8 & 26-35 years & 69 & 3-5 years & 69 \\
\hline Total & 373 & $36-46$ years & 53 & $6-10$ years & 33 \\
\hline \multirow[t]{6}{*}{ Missing } & 11 & $46-65$ years & 70 & $11-20$ years & 53 \\
\hline & & $>65$ years & 12 & 21-30 years & 48 \\
\hline & & Total & 373 & $31-40$ years & 34 \\
\hline & & Missing & 11 & $>40$ years & 12 \\
\hline & & & & Total & 368 \\
\hline & & & & Missing & 16 \\
\hline
\end{tabular}

TABLE 3 Regrouped Basic Information

\begin{tabular}{lll}
\hline Repair company 1 & Group 1 & Not corrupt \\
Repair company 2-4 & Group 2 & Low corruptibility \\
Repair company 5-7 & Group 3 & Medium corruptibility \\
Repair company 8-10 & Group 4 & High corruptibility \\
\hline
\end{tabular}

are described in the following. Firstly, the authors of the initial experiment also used the Chi Square method (Frank and Schulze 2000), which enhances comparability of the results. Secondly, the dependent, as well as the independent variable are non-metric. The Chi-Square Test is in the case of a frequency comparisons a nonparametric test and can therefore be used with this type of data (Cohen 1977) and can take into account more than one variable simultaneously (Malhotra 2012).

Before scrutinising the outcome of the Chi Square analysis, a frequency analysis was conducted in order to see the distribution of respondents. The results are presented in table 2.

As can be seen, the gender distribution was equal. It also becomes apparent that the largest group of respondents were young respondents between 19 and 25 years, which is further reflected in the distribution of work experience. However, as this was an experiment and not a questionnaire, it is argued that external validity does not primarily depend on the equal representation of demographic groups (Lynch 1982). Furthermore, before conducting the Chi Square analysis the ten different repair companies were regrouped into only four groups. This step was taken in order to meet the requirements of the Chi Square Analysis to have at least five respondents in every category (Malhotra 2012). 
TABLE 4 RU_recoded * Wage_Level Crosstabulation

\begin{tabular}{|c|c|c|c|c|c|c|}
\hline & & & & e_level & & Total \\
\hline & & & 1700 & 2400 & 3100 & \\
\hline RU_recoded & 1.00 & (a) & 72.0 & 79.0 & 81.0 & 232.0 \\
\hline & & (b) & 80.4 & 75.5 & 76.1 & 232.0 \\
\hline & & (c) & 31.0 & 34.1 & 34.9 & 100.0 \\
\hline & & (d) & 54.1 & 63.2 & $64 \cdot 3$ & 60.4 \\
\hline & & (e) & -1.8 & 0.8 & 1.1 & \\
\hline & 2.00 & (a) & 28.0 & 21.0 & 19.0 & 68.0 \\
\hline & & (b) & 23.6 & 22.1 & 22.3 & 68.0 \\
\hline & & (c) & 41.2 & 30.9 & 27.9 & 100.0 \\
\hline & & (d) & 21.1 & 16.8 & 15.1 & 17.7 \\
\hline & & (e) & 1.2 & -0.3 & -0.9 & \\
\hline & 3.00 & (a) & 16.0 & 16.0 & 14.0 & 46.0 \\
\hline & & (b) & 15.9 & 15.0 & 15.1 & 46.0 \\
\hline & & (c) & 34.8 & 34.8 & 30.4 & 100.0 \\
\hline & & (d) & 12.0 & 12.8 & 11.1 & 12.0 \\
\hline & & (e) & 0.0 & 0.3 & -0.4 & \\
\hline & 4.00 & (a) & 17.0 & 9.0 & 12.0 & 38.0 \\
\hline & & (b) & 13.2 & 12.4 & 12.5 & 38.0 \\
\hline & & (c) & 44.7 & 23.7 & 31.6 & 100.0 \\
\hline & & (d) & 12.8 & 7.2 & 9.5 & 9.9 \\
\hline & & (e) & 1.4 & -1.2 & -0.2 & \\
\hline Total & & (a) & 133.0 & 125.0 & 126.0 & 384.0 \\
\hline & & (b) & 133.0 & 125.0 & 126.0 & 384.0 \\
\hline & & (c) & 34.6 & 32.6 & 32.8 & 100.0 \\
\hline & & (d) & 100.0 & 100.0 & 100.0 & 100.0 \\
\hline
\end{tabular}

Notes Row headings are as follows: (a) count, (b) expected count, (c) percentage within RU_recoded, (d) percentage within Wage_level, (e) adjusted residual.

Using IBM SPSS version 24, the data was analysed and produced the results, which are presented in table 4.

The Chi Square table reveals in different ways, that there is no significant difference and therefore HO1 and HO2 were not rejected. A first impression can be given by regarding the expected counts and the real counts. It becomes apparent that these values are not highly different in the extracted cross tabulation, which is already a first sign that shows that there might be no association (Malhotra 2012). This impression is confirmed when looking at the Adjusted Residuals. The Adjusted residuals represent Z-Scores that are significant when they exceed the score of 1.96. As can be seen in the cross tabulation, no cells show an adjusted residual that is higher than 1.96 or 
TABLE 5 Chi-Square Tests

\begin{tabular}{lrrr}
\hline Item & Value & DF & AS \\
\hline Pearson Chi-Square & 4.936 & 6 & 0.552 \\
Likelihood Ratio & 4.940 & 6 & 0.551 \\
Linear-by-Linear Association & 1.965 & 1 & 0.161 \\
No. of Valid Cases & 384 & & \\
\hline
\end{tabular}

NOTES DF - degrees of freedom, AS - asymptotic significance (2-sided).

lower than 1.96, which shows that there is no significance (GarciaPerez 2014).

This is further underlined by table 5 . The value of Pearson's Chi Square exceeds the significance level 0.05 substantially. Also the value of 4.936 is far under the critical value of 12.592 that would be necessary to result in a significance for a table with the degree of freedom of 6 and a significance level of 0.05; as there is no significance, the strength of association does not need to be regarded anymore (Malhotra 2012).

\section{Discussion}

The outcome of the experiment showed that the research questions were not affirmed. Which leads to the fact that both но were not rejected:

но1 High wages are not related with different levels of corruption in the private purchasing sector.

Hо2 Low wages are not related to the different levels of corruption in the private purchasing sector.

The result shows that the level of wages is not related to the level of corruptibility of the respondents, when acting as employees in a purchasing decision of the private sector.

This is in accordance with the findings of Frank and Schulze (2003), who also did not find a significant impact of the level of wages on the level of corruptibility, as long as they did not add the determinant of monitoring to their research. Therefore, this result also shows that the mechanism of pure wage level might not work neither in a non-profit organization, such as Frank and Schulze's student's film club, nor in the environment of a multinational company. It also showed that the question posed in Frank and Schulze's paper (2003), if it would make a difference to have a principal instead of the experimenter giving the payment or the wage, can be negated. 


\section{Limitations}

As a form of understanding corruption on a micro-level, using an experiment was perceived as a well-working tool. Nevertheless, the question arises how well respondents can really empathize with the role they play in an experiment. Although literature (Stricker 1957; Opp 1967) sees experiments as a reasonable way to find valid results, in this special case, playing an employee in such a difficult situation might have led to a more risk-taking result. Furthermore, as the respondent only saw one wage level, he/she might not have thought about if he/she perceived the wage level as high or low.

Furthermore, as only imaginary payoffs could be given, it might also have influenced the results. It might be argued that this lead participants to not truly commit to the experiment. Literature argues that participants that are paid in cash might become more attentive to their task, as well as more risk averse (Holt and Laury 2002).

\section{Conclusion}

The current experiment aimed at finding a relation between the level of wages and the level of corruptibility in the private purchasing sector. Respondents were put in the role of employees in the purchasing department of a private company. By classifying the respondents in three different wage groups, it was analysed, if they would respond differently due to their wages, in a situation where they could choose between options of different corruption levels.

Although the results showed that wage levels do not directly impact the level of corruption, the focus on wages showed to be quite interesting. Fixed wages is a clearly understandable instrument that would have led to precise implications for managers. Moreover, the use of wages is also widely debated in corruption literature, which brings this paper to contribute to the discussion by agreeing with the group being critical of the usefulness of fixed wages to corruption.

A possible explanation for the result is the fact that fixed income might not be an incentive that is variable enough. This means that it is neither selective in rewarding the best employees, nor incentivising the employee to work harder (Bamberg, Coenenberg, and Krapp 2008; Jost 2011; Pratt and Zeckenhauser 1985). In addition, the missing link between the conduct of the agent and his/her wage might have led the agent to not feel a connection of being responsible of acting in favour of his/her principal. Sappington (1991) agrees by stating that fixed wages do not take into account the characteristics of the agent and are therefore not sufficiently influencing. 
As the comparison with other authors and the idea of the PAT shows, it becomes also apparent that many other factors could have an influence in the corruptibility of purchasing managers. For the future, it would be desirable to conduct the same experiment, but without the focus on fixed wages. This also seems reasonable, as comparable experiments of other authors that added another variable to wages (Abbink 2000; Frank and Schulze 2000; 2003), did arrive at significant outcomes. Therefore, for example, satisfaction with the work place, monitoring, or the reciprocity, could be added as indirect variables. By singling out the different variables, the structure of this project might give valuable insight in what is important in order to create work places where corruptibility can be as low as possible. This is also supported by Frank and Schulze (2003) that see 'systematical evidence' as a necessity to 'assess the different proposals for fighting corruption.'

The current paper also added findings to the applicability of the PAT in the sector of corruption. In general, it can be said that the discussed advantages of the PAT, such as the clear mechanism it shows and the good applicability, were perceived as such during the experiment, while the stated disadvantages were not apparent. Especially, the advantages of using the PAT in the field of corruption, such as similar participating and decision-making parties, a similar mechanism of the PAT and corruption that includes a common focus on information asymmetry (Dietz 1998; Groenendijk 1997; Graf Lambsdorff 2001), are confirmed with this research. Furthermore, the central focus on institutions of the PAT (Dietz 1998) was seen as well fitting for the type of research that was conducted. Finding out what incentives work, in order to lower corrupt behaviour in employees, can help shape institutions in finding well-working measures.

Finally, this experiment also contributed to the highly discussed field of the role of income in a PAт setting. It was in line with the group of researchers that take a critical attitude against the use of fixed income to prevent corruption (Bamberg, Coenenberg, and Krapp 2008; Jost 2011; Pratt and Zeckenhauser 1985; Sappington 1991).

To sum it up, it can be concluded that fighting greed with money seems to not be a solution - at least not with fixed wages.

\section{Implications for Practice}

The research showed that only concentrating on a high fixed income might not be the most effective way to circumvent corruption. This should lead managers to think about a variable incentive scheme. 
Furthermore, the present research should encourage businesses to support further research that could show how incentive schemes should be framed and what incentives could work to prevent corruption, also in the private sector.

\section{Implications for Research}

Firstly, it needs to be mentioned that the initial secondary research clearly showed that the topic of corruption in the private sector has not received sufficient attention so far. Although, comprehensible reasons from different publications were found that explained the high importance of research in the public sector, numbers from Ernst and Young (2017), Argandoña (2003), and Rashid and Rashid (2012) emphasized the necessity to focus more research on the private sector. Therefore, this paper aimed at adding further insight and drawing attention to the corruptibility in the private sector.

Secondly, the used model by Frank and Schulze can act as a simple model that should be reused with different determinants. Instead of different wage levels, different other factors, such as monitoring or satisfaction with the workplace could be used. This would result in an interesting comparison in order to see, what drives employees to act corrupt.

\section{References}

Abbink, K. 200o. 'Fair Salaries and the Moral Costs of Corruption.' Bonn Econ Discussion Papers 1/2000, University of Bonn, Bonn.

Aidt, T. 2003. 'Economic Analysis of Corruption: A Survey.' The Economic Journal 113:633-52.

Argandoña, A. 2003. 'Private-to-Private Corruption.' Journal of Business Ethics 47 (3): 253-67.

Arthurs, J., and L. Busenitz. 2003. 'The Boundaries and Limitations of Agency Theory and Stewardship Theory in the Venture Capitalist/Entrepreneur Relationship.' Entrepreneurship: Theory and Practice 27:145-62.

Azfar, O., and W. R. Nelson. 2007. 'Transparency, Wages, and the Separation of Powers: An Experimental Analysis of Corruption.' Public Choice 130 (3-4): 471-93.

Bamberg, G., A. Coenenberg, and M. Krapp. 2008. Betriebswirtschaftliche Entscheidungslehre. Munich: Franz Vahlen.

Barr, A., M. Lindelow, and P. M. Serneels. 2004. 'To Serve the Community or Oneself: The Public Servant's Dilemma.' World Bank Policy Research Working Paper 3187, World Bank, Washington, DC.

Becker, G. S., and G. J. Stigler. 1974. 'Law Enforcement, Malfeasance, and Compensation of Enforcers.' The Journal of Legal Studies 3 (1): 1-18. 
Besley, T., and J. McLaren. 1993. 'Taxes and Bribery: The Role of Wage Incentives.' The Economic Journal 103 (416): 119-41.

Boly, A., and O. Armantier. 2011. 'A Controlled Field Experiment on Corruption.' European Economic Review 55 (8): 1072-82.

Broadbent, J., M. Dietrich, and R. Laughlin. 1996. 'The Development of Principal-Agent Contracting and Accountability Relationships in the Public Sector: Conceptual and Cultural Problems.' Critical Perspectives on Accounting 7:259-84.

Cohen, J. 1977. Statistical Power Analysis for the Behavioral Sciences. New York: Academic Press.

Dietz, M. 1998. Korruption - Eine insitutionenökonomische Analyse. Berlin: Arno Spitz.

Dusek, L., A. Ortmann, and L. Lízal. 2005. 'Understanding Corruption and Corruptibility Through Experiments.' Prague Economic Papers 14 (2): 147-62.

Ernst and Young. 2015. 'Fraud and Corruption - The Easy Option for Growth? Europe, Middle East, India and Africa Fraud Survey 2015.' http://www.ey.com/Publication/vwLUAssets/ey-emeia-fraudsurvey/\$FILE/ey-emeia-fraud -survey.pdf

Fehr, E., G. Gächter, and G. Kirchsteiger. 1997. 'Reciprocity as a Contract Enforcement Device: Experimental Evidence.' Econometrica 65 (4): 833-60.

Frank, B., and G. G. Schulze. 200o. 'Does Economics Make Citizens Corrupt?' Journal of Economic Behavior and Organization 43 (1): 101-13.

- 2003. 'Deterrence Versus Intrinsic Motivation: Experimental Evidence on the Determinants of Corruptibility.' Economics of Governance 4 (2): 143-6o.

Garcia-Perez, M. 2014. 'Analysis of Residuals in Contigency Tables: Another Nail in the Coffin of Conditional Approaches to Significance Testing.' Behaviour Research Methods 47 (1): 147-161.

Goel, R. K., and M. A. Nelson. 1996. 'Corruption and Government Size: A Disaggregated Analysis.' Public Choice 97:107-20.

Graf Lambsdorff, J. 2001. 'How Corruption in Government Affect Public Welfare: A Review of Theory.' Discussion Paper, Center for Globalization and Europeanization of the Economy, Georg-August Universität, Göttingen.

- 2002. 'Corruption and Rent-Seeking.' Public Choice 113:97-125.

Gray, C. W., and D. Kaufmann. 1998. 'Corruption and Development.' Finance and Development 35 (1): 7-10.

Groenendijk, N. 1997. 'A Principal-Agent Model of Corruption.' Crime, Law and Social Change 27:227-9.

European Parliamentary Research Services. 2016. The Cost of NonEurope in the Area of Organised Crime and Corruption. Brussels: European Parliamentary Research Services. 
Holt, C. A., and S. Laury. 2002. 'Risk Aversion and Incentive Effects.' American Economic Review 92 (5): 1644-55.

International Monetary Fund. 2016. 'Corruption: Costs and Mitigating Strategies.' IMF Staff Discussion Note SDN/16/05, International Monetary Fund, Washington, DC.

Johnston, M. 2008. 'The Search for Definitions: The Vitality of Politics and the Issue of Corruption.' International Social Science Journal 59:321-35.

Jost, P. 2001. Die Prinizipal-Agenten-Theorie in der Betriebwirtschaftslehre. Stuttgart: Schäffer-Poeschel.

Kiener, S. 1990. Die Principal-Agent-Theorie aus informationsöknomischer Sicht. Heidelberg: Physica.

Kivistö, J. 2008. 'An Assessment of Agency Theory as a Framework for the Government-University Relationship.' Journal of Higher Education Policy and Management 30 (4): 339-50.

Klitgaard, R. 1988. Controlling Corruption. Berkeley, cA: University of California Press.

Levacic, R. 2009. 'Teacher Incentives and Performance: An Application of Principal-Agent Theory.' Oxford Development Studies 37:33-46.

Lynch, J. 1982. 'On the External Validity of Experiments in Consumer Research.' Journal of Consumer Research 9:225-39.

Malhotra, N. K. 2012. Basic Marketing Research. Harlow: Pearson.

Miller, G. 2005. 'The Political Evolution of PA Models.' Annual Review of Political Science 8:203-25.

oEcD. 2016. 'Preventing Corruption in Public Procurement.' http://www .oecd.org/gov/ethics/Corruption-in-Public-Procurement-Brochure .pdf

Opp, K.-D. 1969. 'Das Experiment in den Sozialwissenschaften: Einige Probleme und Vorschläge für seine effektivere Verwendung.' Journal für die Gesamte Staatswissenschaft 125 (1): 106-22.

Ortiz-Ospina, E., and M. Roser. 2016. 'Corruption.' https:// ourworldindata.org/corruption/

Passas, N. 2007. 'Corruption in the Procurement Process/Outsourcing Government Functions: Issues, Case Studies, Implications; Report to Institute for Fraud Prevention.' https://pdfs.semanticscholar.org/ 1bef/4102d1db4dc33ec870eb69604898b8b8ccc6.pdf

Persson, A., B. Rothstein, and J. Teorell. 2010. 'A Failure of AntiCorruption Policies. A Theoretical Mischaracterization of the Problem.' QOG Working Paper Series 2010:19, University of Gothenburg, Gothenburg.

Pramböck, C. 2014. 'Was Einkäufer verdienen.' Der Standard, 23 April. http://derstandard.at/1397521368877/Gehaelter-und-Karriere-im -Einkauf

Pratt, J., and R. Zeckenhauser. 1985. Prinicpals and Agents: The Structure of Business. Boston, mA: Harvard Business School Press. 
Rashid, S., and U. Rashid. 2012. 'Work Motivation Differences between Public and Private Sector.' American International Journal of Social Science 1 (2): 24-33.

Sappington, D. 1991. 'Incentives in Principal-Agent Relationships.' The Journal of Economic Perspectives 5 (2): 45-66.

Schwaiger, M., and A. Meyer. 2011. Theorien und Methoden der Betriebswirtschaftslehre: Handbuch für Wissenschaftler und Studierende. Munich: Franz Vahlen.

Stricker, W. 1957. 'Das Experiment in der Betriebswirtschaftslehre.' Die Unternehmung 11 (2): 39-46.

Transparency International. 2016. People and Corruption: Europe and Central Asia. Berlin: Transparency International.

Van Rijckeghem, C., and B. Weder. 2001. 'Bureaucratic Corruption and the Rate of Temptation: Do Wages in the Civil Service Affect Corruption, and by How Much?' Journal of Development Economics 65 (2): 307-31.

This paper is published under the terms of the AttributionNonCommercial-NoDerivatives 4.o International (CC BY-NC-ND 4.0) License (http://creativecommons.org/licenses/by-nc-nd/4.o/). 